\title{
Construction of cys: lac Gene Fusions in Escherichia coli and Their Use in the Isolation of Constitutive cys $B^{\mathfrak{c}}$ Mutants
}

\author{
By MONIKA HRYNIEWICZ, ANDRZEJ PALUCHA AND \\ M. DANUTA HULANICKA* \\ Institute of Biochemistry and Biophysics, Polish Academy of Sciences, Rakowiecka 36, \\ 02-532 Warsaw, Poland
}

(Received 7 September 1987)

Operon fusions of the lac $Z$ gene to two different genes of the cysteine regulon controlled by the $c y s B$ regulatory protein were isolated. The fusion strains were used for selection of $c y s B$ constitutive mutants. Three $c y s B^{\mathfrak{c}}$ alleles have been characterized and cloned into multicopy plasmids.

\section{INTRODUCTION}

The cysB gene of Salmonella typhimurium or Escherichia coli codes for a regulatory protein (Mascarenhas \& Yudkin, 1980; Baptist et al., 1982) required for expression of all other genes of the cysteine regulon except cysE (Jones-Mortimer, 1968a,b; Kredich, 1971) and cysG (Ostrowski \& Hulanicka, 1979). The cysB alleles from both organisms have been cloned (JaguraBurdzy \& Kredich, 1983), sequenced (Ostrowski et al., 1987) and shown to code for a $36 \mathrm{kDa}$ polypeptide with $95 \%$ protein sequence homology. Maximum expression of the cysteine regulon requires, in addition to a functional $c y s B$ gene product, an internal inducer - $O$-acetyl-L-serine (the cysE gene product) - and sulphur limitation, because cysteine represses the cysteine biosynthetic activities (Jones-Mortimer 1968b; Pasternak et al., 1965; Kredich, 1971). Most known $c y s B$ mutations result in cysteine auxotrophy. In $S$. typhimurium several cys $B$ alleles have been found that cause constitutive expression of the cysteine biosynthetic pathway irrespective of $O$-acetylserine and sulphur source. These alleles, designated $c y s B^{c}$, confer a $\mathrm{Cys}^{+}$phenotype together with resistance to 1,2,4-triazole and selenate (Kredich, 1971; Borum \& Monty, 1976; Sledziewska \& Hulanicka, 1978). So far no $c y s B^{\mathrm{c}}$ mutants of $E$. coli have been described and there has not been an easy way of systematically isolating regulatory cys mutations in this organism.

We employed the technique of Casadaban \& Cohen (1979) to isolate strains in which genes of the lac operon were fused to structural cys genes and thereby placed under the control of the regulatory elements for the cysteine regulon: sulphur source and the $c y s B$ gene product. In this report we describe the construction of $c y s$ : lac operon fusions under $c y s B$ gene control and the use of these fusion strains for selection of $c y s B^{\mathrm{c}}$ mutants in $E$. coli. The $c y s B^{\mathrm{c}}$ alleles were characterized and cloned into multicopy plasmids.

\section{METHODS}

Bacterial strains and bacteriophages. All strains used were derivatives of Escherichia coli K12. Their characteristics are described in Table 1. Muctsdl $\left(\mathrm{Ap}^{\mathrm{r}}\right.$ lac) phage (Casadaban \& Cohen, 1979) was prepared from the lysogenic strain Mal103. $\lambda$ pl(209) was obtained from M. Casadaban. Plvir and T4 phages were used for transductions performed according to Miller (1972) and Wilson et al. (1979), respectively.

Abbreviations: DES, diethyl sulphate; OASS, $O$-acetylserine sulphydrylase; SR, sulphite reductase. 
Table 1. Escherichia coli strains and plasmids

Strain

Mal103

JA199

NK1

EC1119

EC1177

$\mathrm{EC} 1250$

EC2250

EC2251

EC2256

EC2257

EC2266

EC2267

EC2270

EC2271

EC2276

EC2277

EC2278

EC2279

EC2280

EC2281

pGBK5 cysJIH

pDHK14 cysA cysM

pDHK 16 cysB

pMAH2 cysB 302

pMAH3 cysB 303

$\mathrm{F}^{-}$araD
(Mucts) cys $B^{\mathrm{c}} 302$ cysB 303 cys $^{\mathrm{c}} 301$
Plasmids

pMAH1 $\quad$ cysB 301

Genotype

trpEs leu-6 thi $\mathrm{r}^{-} \mathrm{m}_{\mathrm{k}}^{+}$

trpE5 leu-6 thi $\mathrm{r}^{-} \mathrm{m}_{\mathrm{k}}^{+}$cysB

trpE5 leu-6 thi $\mathrm{r}^{-} \mathrm{m}_{\mathrm{k}}^{+}$cysA

eu- 6 thi $\mathrm{r}^{-} \mathrm{m}_{\mathrm{k}}^{+}$cysB

araD139 $\triangle$ lacU169 rpsL thi fla trp-3

cys329:: Mudl(Ap lac)

$\mathrm{F}^{-}$araD139 $\Delta$ lacU169 rpsL thi fla trp-3

cys342::Mudl(Ap lac)

$\mathrm{F}^{-}$araD139 $\Delta$ lacU169 rpsL thi fla trp-3 cys329:: lac imm $^{\lambda}$

$\mathrm{F}^{-}$araD139 $\Delta$ lacU169 rpsL thi fla trp-3 cys342: : lac imm ${ }^{\lambda}$

araD139 $\Delta$ lacU169 rpsL thi fla cys329:: lac imm ims $^{\lambda}$ cy

$\mathrm{F}^{-}$araD139 $\triangle$ lacU169 rpsL thi fla cys342: :lac imm $^{\lambda}$ cysB

$F^{-}$araD139 $\Delta$ lacU169 rpsL thi fla cys329: : lac imm ${ }^{\lambda}$

$\mathrm{F}^{-}$araD139 $\triangle$ lacU169 rpsL thi fla cys342: : lac imm ${ }^{\lambda}$

$\mathrm{F}^{-}$araD139 $\Delta$ lacU169 rpsL thi fla cys329:: lac imm $^{\lambda}$

$\mathrm{F}^{-}$araD139 $\Delta$ lacU169 rpsL thi fla cys329::lac imm ${ }^{\lambda}$

$\mathrm{F}^{-}$araD139 $\Delta$ lacU169 rpsL thi fla cys342::lac imm ${ }^{\lambda}$

leu-6 thi $\mathrm{r}^{-} \mathrm{m}_{\mathrm{k}}^{+}$cysB $B^{\mathrm{c}} 302$

leu-6 thi $\mathrm{r}^{-} \mathrm{m}_{\mathrm{x}}^{+}$cys $B^{\mathrm{c}} 303$

leu- 6 thi $\mathrm{r}^{-} \mathrm{m}_{\mathrm{k}}^{+}$cysB $B^{\mathrm{c}} 301$

* Strains derived from cys : : Mud(Ap lac) in which $\lambda \mathrm{pl}(209)$ has been lysogenized and the intervening Mu has subsequently been deleted.

Media and growth conditions. Sulphate-free medium (SF) was the minimal medium C, in which the sulphur source was $0.1 \mathrm{mM}$-L-cystine or $1 \mathrm{mM}$-L-djenkolic acid. Glucose was added to $0.5 \%$, amino acids to $0.2 \mathrm{mM}$, and ampicillin and tetracycline to 50 and $25 \mathrm{mg} \mathrm{l}^{-1}$, respectively, when required. All solid media contained $1.5 \%(\mathrm{w} / \mathrm{v})$ agar. LB liquid medium or agar plates (Miller, 1972) were used as rich media. Lactose solid medium contained $1 \%$ $(\mathrm{w} / \mathrm{v})$ lactose as sole carbon source. Bacterial cultures were incubated with aeration at $37^{\circ} \mathrm{C}$.

Enzyme assays. $\beta$-Galactosidase (EC 3.2.1.23) was assayed in toluenized cells with $o$-nitrophenyl $\beta$-Dgalactopyranoside as substrate (Miller, 1972). $O$-Acetylserine sulphydrylase (OASS; EC 4.2.99.8) was determined as described by Becker $e$ t al. (1969). Sulphite reductase (SR, EC 1.8.1.2) was assayed by the method of deVito \& Dreyfuss (1964) and sulphate permease according to Karbonowska et al. (1977). Protein was determined by the biuret method (Gornall et al., 1949) with bovine serum albumin as standard.

Isolation of cys : lac fusion strains. Preparation of Mud1(Ap lac) phage lysate and conditions of infection of $E$. coli were as described by Casadaban \& Cohen (1979). Conversion of Mudl (Ap lac) lysogens to $\lambda$ pl(209) lysogens was done as described by Komeda \& Iino (1979) and Gowrishankar \& Pittard (1982).

Selection of cysB constitutive mutants. Portions $(0.2 \mathrm{ml})$ of overnight cultures of the cys : lac fusion strains were spread on lactose plates supplemented with $0.1 \mathrm{mM}-\mathrm{L}-\mathrm{cystine}$, and a $3 \mathrm{MM}$ Whatman paper disc saturated with $20 \mu \mathrm{l}$ DES was placed in the centre of each plate. After overnight incubation at $37^{\circ} \mathrm{C}$, fast-growing colonies were picked up, grown on L-cystine or L-djenkolate and tested for OASS activity in toluenized cells.

Cloning techniques. DNA of plasmids pBR322 or pBR325 was prepared by the alkaline lysis method and purified by $\mathrm{CsCl}$ gradient centrifugation (Maniatis et al., 1982). Chromosomal DNA was prepared according to Silhavy et al. (1984). Vector and chromosomal DNA were separately digested with $E c o$ RI restriction endonuclease, mixed in a ratio of $1: 5(\mathrm{w} / \mathrm{w})$ and ligated with T4 DNA ligase at $14^{\circ} \mathrm{C}$ overnight. Transformation of $E$. coli was done by the method of Kushner (1978). 
Table 2. Activities of $\beta$-galactosidase in cys : :lac fusion strains

The results are means of three to five experiments; the deviations from these means were less than $7 \%$. $\mathrm{RI}$, repression index: the ratio of the enzyme activity of bacteria grown on L-djenkolic acid to that of bacteria cultured on L-cystine. CT, L-cystine ( $0.1 \mathrm{mM})$; $\mathrm{Dj}$, L-djenkolic acid (1 mM).

\begin{tabular}{|c|c|c|c|c|}
\hline \multirow[b]{2}{*}{ Strain } & \multirow[b]{2}{*}{ Pertinent genotype } & \multicolumn{2}{|c|}{$\begin{array}{c}\beta \text {-Galactosidase } \\
\text { (Miller units) }\end{array}$} & \\
\hline & & CT & $\mathrm{Dj}$ & RI \\
\hline EC2250 & cys329::Mudl(Ap lac) & 26 & 234 & \\
\hline EC2251 & cys342::Mudl(Ap lac) & 35 & 347 & \\
\hline $\mathrm{EC} 2256$ & cys329:: :ac imm ${ }^{\lambda}$ & 26 & 276 & 10 \\
\hline EC2257 & cys342: : lac imm ${ }^{\lambda}$ & 27 & 294 & 10 \\
\hline
\end{tabular}

Table 3. Activities of $S R$ and $O A S S$ in fusion strains

Enzyme activities of the control strain grown on L-djenkolic acid as sulphur source were taken as $100 \%$; these values were $12 \mathrm{nmol} \mathrm{S}^{2-} \mathrm{min}^{-1}\left(\mathrm{mg} \text { protein) }{ }^{-1} \text { for SR and } 7.5 \text { units (mg protein) }\right)^{-1}$ for OASS.

\begin{tabular}{|c|c|c|c|}
\hline \multirow[b]{2}{*}{ Strain } & \multirow[b]{2}{*}{ Pertinent genotype } & \multicolumn{2}{|c|}{$\begin{array}{l}\text { Enzyme activity } \\
(\% \text { of control })\end{array}$} \\
\hline & & SR & OASS \\
\hline EC1250 & cys $^{+}$ & 100 & 100 \\
\hline EC2250 & cys329::Mudl(Ap lac) & 96 & 108 \\
\hline EC2251 & cys $342:$ :Mud1(Ap lac) & 2 & 96 \\
\hline EC2256 & cys $329::$ lac imm $^{\lambda}$ & 98 & 102 \\
\hline EC2257 & cys $342::$ lac imm $^{\lambda}$ & 4 & 94 \\
\hline
\end{tabular}

\section{RESULTS}

Isolation and characterization of cys : lac fusion strains

Strain EC1250 ( $\Delta \mathrm{lac}$ ) was mutagenized with Mudl(Ap lac) phage and lysogens containing random insertions of Mudl were selected at $30^{\circ} \mathrm{C}$ as ampicillin-resistant colonies on LB agar plates supplemented with $0.1 \mathrm{mM}$-L-cystine. Of about $10^{4}$ replica-plated lysogens, 160 had acquired new auxotrophic mutations, and 26 of these were cysteine auxotrophs. Ten of the cysteine-requiring Mud1(Ap lac) lysogens expressed $\beta$-galactosidase at high levels and were able to utilize lactose as sole carbon source. Two fusion strains (EC2250 and EC2251) were chosen for further study. In these strains $\beta$-galactosidase expression was regulated by sulphur source in the growth medium (derepressed on L-djenkolate and repressed on L-cystine: Table 2) and the lac genes were fused to two different regulatory regions of the cysteine genes (see below). Because Mudl(Ap lac) fusions tend to undergo rearrangements (Mud prophage is still capable of further transpositions) we stabilized these cys : :Mudl(Ap lac) fusion strains by converting them to $\lambda$ p1(209) lysogens free from intervening $\mathrm{Mu}$ and bla sequences. The resulting strains, EC2256 and EC2257, showed the same dependence of $\beta$-galactosidase activity on sulphur source as the original cys: : Mudl(Aplac) strains (Table 2).

The cys: : lac fusions were characterized by enzyme assays and genetic mapping. The fusion cys 342 : : lac (strain EC2251 and its $\lambda$-lysogenic derivative, EC2257) has been identified as a fusion of lac genes to the regulatory region of the cysJIH operon. The cysJI genes ( 59 unit on the $E$. coli chromosome) code for two polypeptides of SR. The following data support this location of the cys342: : lac fusion: (a) lack of SR activity in crude extracts of strains EC2251 and EC2257 (Table 3); (b) complementation of cysteine auxotrophy by plasmid pGBK 5 carrying the cys JIH region of the $S$. typhimurium chromosome; and $(c) 10 \%$ linkage of the cys mutation with the $s r l$ marker ( 58 unit on the $E$. coli chromosome) in T-4-mediated transduction (data for $b$ and $c$ not shown).

The cys329: : lac fusion strains (EC2250 and the corresponding $\lambda$-lysogen, EC2256) had wildtype SR and OASS activities (Table 3). The complementation of cysteine auxotrophy by 
Table 4. Activity of sulphate permease

$\begin{array}{clc}\text { Strain } & \text { Pertinent genotype } & \begin{array}{c}\text { Sulphate permease } \\ {\left[\mathrm{pmol} \mathrm{SO}_{4}^{2-} \mathrm{min}^{-1} \mathrm{ml}^{-1}\right.} \\ \left(\mathrm{OD}_{650} \mathrm{unit}^{-1}\right]\end{array} \\ \text { EC1250 } & \text { cys } & 6 \\ \text { EC1119 } & \text { cys } A & 690 \\ \text { EC2256 } & \text { cys329::lac } & 0.0 \\ & & 4.8\end{array}$

Table 5. Effect of cysB on expression of cys: : lac fusions

\begin{abstract}
All strains were $\mathrm{Trp}^{+}$transductants from a cross with strain EC1177 (cysB) as a donor. Because the recipient strains were cysteine auxotrophs the $c y s B$ transductants were identified as those with significantly reduced OASS activity (data not shown). The deviations from mean values (three to five experiments) were less than $7 \%$.
\end{abstract}

\begin{tabular}{|c|c|c|c|}
\hline \multirow[b]{2}{*}{ Strain } & \multirow[b]{2}{*}{ Pertinent genotype } & \multicolumn{2}{|c|}{$\begin{array}{l}\beta \text {-Galactosidase } \\
\text { (Miller units) }\end{array}$} \\
\hline & & $\mathrm{CT}^{*}$ & $\mathrm{Dj}^{*}$ \\
\hline EC2270 & cys329::lac & 38 & 386 \\
\hline EC2266 & cys $329::$ lac cys $B$ & 1 & 3 \\
\hline EC2271 & cys $342:: l a c$ & 50 & 423 \\
\hline EC2267 & cys $342::$ lac cys $B$ & 2 & 3 \\
\hline
\end{tabular}

plasmid pDHK 14 carrying cys $A$ and $c y s M$ genes of $S$. typhimurium, and the lack of sulphate permease activity in strain EC2256 (Table 4) allowed us to localize the cys329: : lac fusion in the cys $A$ region.

\title{
Selection of cysB regulatory mutants
}

The rationale for the use of $c y s:$ : lac fusion strains to select $c y s B$ regulatory mutants required $\beta$-galactosidase expression to be controlled by the $c y s B$ gene product. In order to prove that these fusion strains fulfilled this requirement the cysB mutant allele from strain EC1177 was introduced into fusion strains by P1 vir-mediated transduction. Assay of $\beta$-galactosidase activity showed an almost complete lack of lac $Z$ gene expression in $c y s B$ transductants (Table 5).

The common phenotype of strains with $c y s$ : : lac fusions under $c y s B$ control was the ability to grow on lactose as sole carbon source when L-djenkolic acid but not L-cystine was provided as sulphur source. This feature was exploited to search for $c y s B$ constitutive mutants among clones expressing the $\mathrm{Lac}^{+}$phenotype in the presence of cystine. Fusions with two different regulatory regions of the cys structural genes (strains EC2270 and EC2271, Trp ${ }^{+}$derivatives of the parental strains EC2256 and EC2257) were used for selection of $\mathrm{Lac}^{+}$clones resistant to cystine repression after DES mutagenesis. Fast-growing colonies were found on lactose plates supplemented with L-cystine at a frequency of $10^{-6}-10^{-7}$. Twenty-four stable cystine-resistant $\mathrm{Lac}^{+}$clones were screened for OASS activity in toluenized cells grown in the presence of Lcystine or L-djenkolate. In three of the mutant strains examined (EC2276, EC2277 and EC2278) the OASS levels were almost the same for cultures grown on both sulphur sources (data not shown). In order to check if constitutive levels of OASS resulted from mutation in the cysB gene (linked to the trp operon) P1 lysates of strains EC2276, EC2277 and EC2278 were used for transduction of a cysB strain (NK1) to tryptophan prototrophy. About $70 \%$ of the transductants were $\mathrm{Trp}^{+} \mathrm{Cys}^{+}$.

The activities of SR and OASS in these transductants (strains EC2279, EC2280 and EC2281) are presented in Table 6 . The activities of both enzymes were nearly the same for cultures grown on L-cystine or L-djenkolate, with a repression index of $1-1 \cdot 7$, in contrast to that of $8-10$ for the wild-type strain. 
Table 6. Activities of $S R$ and $O A S S$ in $c y s B^{\mathrm{c}}$ strains

The results are presented as percentages of the SR and OASS activities of the wild-type strain grown on L-djenkolic acid; these values were $110 \mathrm{nmol} \mathrm{S}^{2-} \mathrm{min}^{-1}$ (mg protein) ${ }^{-1}$ for SR and 6.5 units (mg protein $)^{-1}$ for OASS. ND, Not determined; other abbreviations as in Table 2.

\begin{tabular}{|c|c|c|c|c|c|c|c|}
\hline \multirow[b]{2}{*}{ Strain } & \multirow{2}{*}{$\begin{array}{l}\text { Pertinent } \\
\text { genotype }\end{array}$} & \multicolumn{2}{|c|}{$\underset{\text { (\% of control) }}{\mathrm{SR}}$} & \multirow[b]{2}{*}{ RI } & \multicolumn{2}{|c|}{$\begin{array}{c}\text { OASS } \\
(\% \text { of control })\end{array}$} & \multirow[b]{2}{*}{ RI } \\
\hline & & $\mathrm{CT}$ & $\overrightarrow{\mathrm{Dj}}$ & & $\mathrm{CT}$ & $\overrightarrow{\mathrm{Dj}}$ & \\
\hline JA199 & Wild-type & 12 & 100 & $8 \cdot 3$ & 9.6 & 100 & $10 \cdot 4$ \\
\hline EC2279 & cysB $B^{\mathrm{c}} 302$ & 93 & 120 & $1 \cdot 3$ & 75 & 102 & 1.4 \\
\hline EC2280 & cysB $^{\mathrm{C}} 303$ & 45 & 72 & 1.6 & 53 & 84 & 1.6 \\
\hline EC2281 & $\operatorname{cys}^{\mathrm{C}} 301$ & 101 & 109 & $1 \cdot 1$ & 109 & 127 & $1 \cdot 2$ \\
\hline NK1 & cys $B$ & ND & 3 & & ND & 5 & \\
\hline $\mathrm{NK} 1 / \mathrm{pMAH} 1$ & cys $B^{\mathrm{c}} 301$ & 83 & 117 & $1 \cdot 4$ & 93 & 140 & 1.5 \\
\hline $\mathrm{NK} 1 / \mathrm{pMAH} 2$ & cys $B^{\mathrm{c}} 302$ & 78 & 133 & 1.7 & 85 & 120 & \\
\hline $\mathrm{NK} 1 / \mathrm{pMAH} 3$ & cys $B^{\mathrm{C}} 303$ & 44 & 79 & 1.8 & 54 & 107 & $2 \cdot 0$ \\
\hline
\end{tabular}

\section{Cloning of cys $B^{\mathrm{c}}$ mutant alleles}

The wild-type $c y s B$ allele was originally cloned in a $5 \mathrm{~kb} E c o \mathrm{RI}$ restriction fragment of the $E$. coli chromosome (plasmid pDHK 16). Therefore, we used EcoRI for shot-gun cloning of the newly isolated $c y s B^{c}$ alleles into a multicopy plasmid. Genomic DNA of strains EC2279 $\left(c y s B^{\mathrm{c}} 302\right), \mathrm{EC} 2280\left(c y s B^{\mathrm{c}} 303\right)$ and $\mathrm{EC} 2281$ (cysB $\left.B^{\mathrm{c}} 301\right)$ was digested with EcoRI and ligated with $E c o$ RI-cleaved DNA of plasmids pBR322 or pBR325. The ligation mixtures were used to transform the $E$. coli cys $B$ strain NK1 to cysteine prototrophy. A few Cys ${ }^{+}$transformants were found; these were analysed by agarose gel electrophoresis for the presence of plasmids containing a $5 \mathrm{~kb}$ Eco RI chromosomal insert.

The following plasmids were isolated: pMAH1, consisting of the pBR325 vector and a $5 \mathrm{~kb}$ EcoRI fragment of EC2281 (cysB 301$)$ chromosomal DNA; and pMAH2 and pMAH3, consisting of the pBR322 vector and $5 \mathrm{~kb}$ EcoRI chromosomal inserts of EC2279 (cysB $\left.B^{\mathrm{c}} 302\right)$ and $\mathrm{EC} 2280$ (cys $\left.B^{\mathrm{c}} 303\right) \mathrm{DNA}$, respectively. The identity of the chromosomal inserts of the pMAH plasmids with that of plasmid pDHK 16 was shown by double $E c o \mathrm{RI} / S a l I$ restriction analysis. The introduction of plasmids containing each of the cloned $c y s B^{c}$ alleles into the $c y s B$ strain NK 1 resulted in derepressed levels of cysteine biosynthetic enzymes regardless of the sulphur source in the medium (Table 6); similar results have been obtained with another $E$. coli cys $B$ strain (EC1258) and with an $S$. typhimurium cys $B$ strain (TK3213) bearing these plasmids (data not shown).

\section{DISCUSSION}

Fusions of the $E$. coli lac $Z$ gene to regions controlling other genes have become one of the most powerful tools for studying the regulation of gene expression (Silhavy \& Beckwith, 1985). Application of the defective phage Mudl(Ap lac) constructed by Casadaban \& Cohen (1979) allows simple in vivo isolation of lac operon fusions to almost any gene of interest. In such fusion strains the easily measurable $\beta$-galactosidase activity reflects the level of transcription from the promoter to which the lac operon is fused.

One of the many uses of the lac fusion technique is employment of fusion strains to isolate new classes of regulatory mutants. We used the procedure of Casadaban \& Cohen (1979) to generate fusions linking lac genes to $c y s$ gene promoters controlled by sulphur source and the $c y s B$ regulatory protein. Two strains with $l a c$ genes fused to the $c y s A$ or $c y s J I H$ regulatory regions (EC2250 and EC2251 and their $\lambda$-lysogenic derivatives, EC2256 and EC2257, respectively) were characterized and chosen for selection of $c y s B$ constitutive mutants in $E$. coli. Expression of the lac $Z$ gene in both fusion strains required a functional $c y s B$ gene product and sulphur limitation; the strains were therefore able to utilize lactose as sole carbon source when djenkolate but not cystine was provided as sulphur source. 
We reasoned that secondary mutations enabling these fusion strains to escape cystine repression might belong to two categories: (1) $c y s B^{\mathrm{c}}$ mutations, and (2) mutations in regulatory regions of $c y s$ genes fused to lac $Z$. Mutants able to use lactose as sole carbon source in the presence of cystine arose with relatively high frequency $\left(10^{-6}-10^{-7}\right)$ both spontaneously and after DES mutagenesis of $c y s J I:: l a c$ and $c y s A$ : : lac fusion strains. Among 16 clones resistant to cystine repression analysed, two mutants (EC2276 and EC2277) derived from the cysA: :lac strain and one mutant (EC2278) derived from the cysJI::lac strain expressed OASS at constitutive levels (independently of sulphur limitation). The mutations resulting in constitutive expression of cysteine enzymes in these strains were mapped in the $c y s B$ region. The transfer of each of the $c y s B^{c}$ alleles to a $c y s B$ strain by $P 1$ transduction resulted in cysteine prototrophy, constitutive levels of two enzymes representative of the cysteine biosynthetic pathway, SR and OASS, and also in resistance to 1,2,4-triazole and selenate. The features of the $c y s B^{\mathfrak{c}}$ alleles isolated were similar to those of previously described $c y s B^{\mathbf{c}}$ mutations in $S$. typhimurium (Kredich, 1971; Borum \& Monty, 1976; Sledziewska \& Hulanicka, 1978).

As the first step toward detailed characterization of $E$. coli $c y s B^{\mathfrak{c}}$ alleles by sequence analysis we cloned them into multicopy plasmids. The introduction of plasmids carrying cloned $c y s B^{c}$ alleles into a cys $B$ strain resulted in derepressed levels of cysteine biosynthetic enzymes similar to those in strains with a single copy of the respective allele.

The use of strains with $l a c$ genes fused to structural $c y s$ genes controlled by $c y s B$ offers an easy way to isolate a large number of both $c y s B^{\mathrm{c}}$ mutations and mutations in the regulatory regions of cys genes that change their response to regulatory effectors of the cysteine regulon. A similar approach has been used to isolate mal $^{\mathrm{c}}$ mutants (Debarbouille et al., 1978). Fusions of lacZ to the malPQ operon were constructed. The basal level of $\beta$-galactosidase in these strains was too low to allow growth on lactose, and only colonies with $\mathrm{malT}^{\mathrm{c}}$ mutations could use lactose as sole carbon source.

This work was supported by the Polish Academy of Sciences within the project 3.13.

\section{REFERENCES}

Baptist, E. W., Hallquist, S. G. \& Kredich, N. M. (1982). Identification of the Salmonella typhimurium cys $B$ gene product by two-dimensional protein electrophoresis. Journal of Bacteriology 151, 495-499.

BeCKER, M. A., KREDICH, N. M. \& TOMKINS, G. M. (1969). The purification and characterization of $O$ acetylserine sulfhydrylase A from Salmonella typhimurium. Journal of Biological Chemistry 244, 24182427.

BoRUM, P. R. \& MonTy, K. J. (1976). Regulatory mutants and control of cysteine biosynthetic enzymes in Salmonella typhimurium. Journal of Bacteriology 125, 94-101.

Casadaban, M. J. \& Cohen, S. N. (1979). Lactose gene fused to exogenous promoter in one step using Mulac bacteriophage: in vivo probe for transcriptional control sequences. Proceedings of the National Academy of Sciences of the United States of America 76, 4530-4533.

Debarbouille, M., Shuman, H. A., Silhavy, T. J. \& SchwartZ, M. (1978). Dominant constitutive mutations in malT, the positive regulator gene of the maltose regulon in Escherichia coli. Journal of Molecular Biology 124, 359-371.

Gornall, A. G., Bardawill, C. J. \& David, M. M. (1949). Determination of serum proteins by means of the biuret reaction. Journal of Biological Chemistry 177, 751-766.

Gowrishankar, J. \& Pittard, J. (1982). Construction from $\mathrm{Mud} 1\left(\mathrm{Ap}^{\mathrm{r}} \mathrm{lac}\right)$ lysogens of lambda bacterio- phage bearing promoter-lac fusions: isolation of ppheA-lac. Journal of Bacteriology 150, 1122-1129.

HUlANICKa, M. D., GaRRET, C., JaGURA-BURdZy, G. \& KREDICH, N. M. (1986). Cloning and characterization of the cys $A M K$ region of Salmonella typhimurium. Journal of Bacteriology 168, 322-327.

JAGURA-BuRDzy, G. \& HulaniCKa, D. (1981). Use of gene fusions to study expression of $c y s B$, the regulatory gene of the cysteine regulon. Journal of Bacteriology 147, 744-751.

JAGURA-BuRdZY, G. \& KREDICH, N. M. (1983). Cloning and physical mapping of the cys $B$ region of Salmonella typhimurium. Journal of Bacteriology 155 , 578-585.

JONES-MORTIMER, M. C. $(1968 a)$ ). Positive control of sulphate reduction in Escherichia coli: isolation, characterization and mapping of cysteineless mutants of E. coli K12. Biochemical Journal 110, 589595.

Jones-Mortimer, M. C. (1968b). Positive control of sulphate reduction in Escherichia coli: the nature of the pleiotropic cysteineless mutants of $E$. coli $\mathrm{K} 12$. Biochemical Journal 110, 597-602.

KarbonowsKa, M. D., Wiater, A. \& Hulanicka, M. D. (1977). Sulphate permease of Escherichia coli K12. Acta biochimica polonica 24, 329-334.

KOMEDA, Y. \& IINO, T. (1979). Regulation of expression of the flagellin gene (hag) in Escherichia coli K12: analysis of hag-lac fusions. Journal of Bacteriology 139, 721-729. 
KREDICH, N. M. (1971). Regulation of L-cysteine biosynthesis in Salmonella typhimurium. I. Effects of growth on varying sulfur sources and $O$-acetyl-Lserine on gene expression. Journal of Biological Chemistry 246, 3474-3484.

KUSHNER, S. R. (1978). An improved method for transformation of Escherichia coli with ColE1derived plasmids. In Genetic Engineering, pp. 17-22. Edited by $\mathrm{H}$. W. Boyer \& S. Nicosia. New York: Elsevier/North Holland.

Maniatis, T., Fritsch, E. F. \& SambrooK, J. (1982). Molecular Cloning : a Laboratory Manual, pp. 90-94. Cold Spring Harbor, NY: Cold Spring Harbor Laboratory.

Mascarenhas, D. M. \& YUdKIN, M. D. (1980). Identification of a positive regulatory protein in Escherichia coli: the product of cysB gene. Molecular and General Genetics 177, 535-539.

MilleR, J. H. (1972). Experiments in Molecular Genetics. Cold Spring Harbor, NY: Cold Spring Harbor Laboratory.

Ostrowski, J. \& Hulanicka, D. (1979). Constitutive mutation of cys $J I H$ operon in a cysB deletion strain of Salmonella typhimurium. Molecular and General Genetics 175, 145-149.
Ostrowski, J., JaGURA-BuRdzy, G. \& KREDICH, N. M. (1987). DNA sequences of the cys $B$ regions of Salmonella typhimurium and Escherichia coli. Journal of Biological Chemistry 262, 5999-6005.

Pasternak, C. A., Ellis, R. J., Jones-Mortimer, M. C. \& Crichton, C. E. (1965). The control of sulphate reduction in bacteria. Biochemical Journal 96, 270-275.

Silhavy, T. J. \& Beckwith, J. R. (1985). Uses of lac fusions for the study of biological problems. Microbiological Reviews 49, 398-418.

Silhavy, T. J., Berman, M. L. \& ENQuist, L. W. (1984). Experiments with Gene Fusions. Cold Spring Harbor, NY: Cold Spring Harbor Laboratory.

SLEDZIEWSKA, E. \& Hulanicka, D. (1978). Method of isolation of cysteine constitutive mutants of the cysteine regulon in Salmonella typhimurium. Molecular and General Genetics 165, 289-293.

DEVIto, P. C. \& Dreyfuss, J. (1964). Metabolic regulation of adenosinetriphosphate sulfurylase in yeast. Journal of Bacteriology 88, 1341-1348.

Wilson, G. G., Young, K. K. Y. \& Edlin, G. J. (1979). High-frequency generalized transductions by bacteriophage T4. Nature, London 280, 80-82. 